\title{
A study of how English-speaking learners of Spanish in the beyond-basic stage express temporality in personal narratives
}

Un estudio sobre la expresión de la temporalidad en narrativas personales escritas por estudiantes angloparlantes de español de nivel de adquisición más allá del básico

Jessie Carduner

Kent State University,

Department of Modern and

Classical Language Studies jcardune@kent.edu
Daniel Alex Castañeda Kent State University, Department of Modern and

Classical Language Studies dcastane@kent.edu 


\section{Abstract}

This qualitative, concept-oriented, corpus-driven study investigated the function and form of temporal words, phrases, and clauses in their discursive context in 34 personal narratives written by English-speaking learners of Spanish in a U.S. third-year college-level Spanish course, collected over multiple semesters. The results showed that learners at the beyond-basic stage used time expressions abundantly to complement their fairly well-developed but still evolving verb system. Temporal expressions were used most often to order events and actions chronologically and, secondly, for discourse management. Indicators of frequency and manner were rarer. Students most often relied on the principle of natural order, presenting events and actions in the order in which they occurred with no intervening time words. In order of decreasing frequency, learners employed verbless temporal adverbial phrases, expressions containing multiple time words, and temporal clauses. Genre, proficiency, and assignment instructions seemed to have influenced how the learners communicated temporality.

Keywords: concept-oriented; adverbials; corpus analysis; discourse organization; temporal expressions

\section{Resumen}

Esta investigación cualitativa de corpus de enfoque conceptual analizó funciones y formas estructurales de palabras, frases y cláusulas temporales en 34 narrativas personales escritas por universitarios angloparlantes en un curso de español de tercer año, recopiladas durante varios semestres consecutivos. Según los resultados, los estudiantes en la etapa más allá de la básica utilizaron abundantemente expresiones temporales para complementar un sistema verbal desarrollado, pero todavía en proceso de evolución. Utilizaron expresiones temporales mayormente para estructurar sucesos y acciones cronológicamente $\mathrm{y}$, en segundo lugar, para organizar el discurso. Los indicadores de frecuencia y manera se usaron rara vez. Los estudiantes utilizaron frecuentemente el principio de orden natural presentando sucesos y acciones en el orden en que ocurrieron sin utilizar palabras o frases léxicamente asociadas con el tiempo. En orden decreciente de uso, emplearon frases adverbiales sin verbo, segmentos con múltiples frases temporales y cláusulas temporales. El género, la competencia lingüística y las instrucciones para la tarea, parecen haber influido en la manera en que los alumnos comunicaron la temporalidad.

Palabras clave: enfoque conceptual; adverbiales; análisis de corpus; organización discursiva; expresiones temporales 


\section{Introduction}

The ability to narrate and describe in major time frames distinguishes advanced writers from intermediate ones (ACTFL, 2012). To be an "independent" language user, a learner must be able to "describe experiences and events, dreams, hopes and ambitions" (Council of Europe, 2001). Languages offer a variety of means to convey time (Klein, 2009a, 2009b; Klein, Dietrich \& Noyau, 1993; Slobin \& Bocaz, 1988), which involve a combination of lexical, morphological, syntactic, and pragmatic devices (Klein et al., 1993); yet, research on the acquisition of temporality has focused primarily on tense and aspect marking, much less so on the other devices (e.g., Hickmann \& Hendriks, 2015; Klein et al., 1993). With some exceptions (e.g., Bardovi-Harlig, 1994, 1995; Bestgen \& Costermans, 1997), most of the researchers on learners' expression of time in narratives have investigated oral data (e.g., Dietrich, Klein \& Novau, 1995; Hickmann \& Hendriks, 2015; López, 2000) instead of written texts, often with uninstructed learners. In the present corpus-based study, the researchers sought to complement prior research by examining how instructed learners of Spanish in a third-year university course express temporality in written personal narratives.

\section{Literature review}

Narrating involves mediating "a series of events that are temporally configured in a structure characterized by a beginning, a middle, and an end" (Allison, 1994: 109). As such, narratives are replete with expressions of temporality (Smith, 2003; Whitworth, Classen, Leitão \& Webster, 2015; Zwaan, 1996), rendering them particularly suitable for studying the development of temporality in a second language (Bardovi-Harlig, 2013). To provide the background for our study, we first discuss the nature of narratives. Next, we briefly summarize the linguistic resources available for expressing 
temporality in narratives. Finally, we examine prior studies on second-language learners' development of temporality.

\subsection{Narratives}

Labov and Waletzky (1967) and Labov (1972) observed that narratives contain six structural elements. The abstract provides a summary of the upcoming story. The orientation provides the setting, identifying the time, place, persons, and situation. The complicating action, or plot, relates the main events of the narrative. Evaluations reveal the narrator's attitude toward the events, emphasizing the relative importance of some narrative units over others. The resolution presents the outcome. Finally, the coda indicates the relevance of the narration to the present time. The abstract and coda are optional, and both the orientation and evaluation may occur either before or as part of the complicating action and resolution (Eggins \& Slade, 1997).

For Reese et al. (2011), who based their work largely on Labov and Waletzky's (1967) model, coherence in personal narratives is achieved along three essential but independent dimensions: context, temporal ordering, and theme. Context, corresponding to Labov and Waletzky's orientation, tells the receiver where and when an event takes place. Temporal ordering assists the receiver in inferring the order "in which the original actions within an event took place, either from the sequencing of these actions or from linguistic markers of temporality" (Reese et al., 2011: 432). Theme relates to the "point of the story" and should include a high point or climax, a resolution, and affective and evaluative information.

Temporal ordering of narrative sequences is often implicit (e.g., Virtanen, 1992; Zwaan, 1996). For instance, if a speaker were to utter the following three sentences — "At eight I got up. I washed my hair. I brushed my teeth" - the listener would normally infer that the speaker first got up and then washed his hair and then brushed his teeth (example from Starren, 2001: 40). This type of inference has been labeled the iconicity assumption (Vir- 
tanen, 1992; Zwaan, 1996). When narrators imply sequentiality by relating a series of events in the order in which they occurred, they are said to be applying the principle of natural order (PNO) (Bardovi-Harlig, 1994; Klein, 1995; Starren, 2001).

Although PNO is common in narrative discourse, skilled narrators often present events out of sequence (Reese et al., 2011; Zwaan, Madden \& Stanfield, 2001); however, in "a temporally steered text, deviations from temporal sequentiality and temporal adjacency must be marked" (Virtanen, 1992: 185) to clarify the order and maintain coherence. Temporal markers assist readers in processing time shifts (Zwaan, 1996). "By signaling discontinuities in discourse, these devices suspend the search for continuity when the latter is weak" (Bestgen \& Costermans, 1997: 201).

\subsection{Temporal markers}

The expression of time is "close to mandatory" in many languages because it is morphologically marked on verbs (Klein, 2009a: 1; 2009b: 39); however, even in highly inflected languages like Spanish, inflections provide only limited temporal information (Méndez García de Paredes, 1990; Zwaan, 1996). Although tense may indicate when an event occurred vis-à-vis the time of speaking or writing, lexical items like adverbs and adverbials (i.e., adverbials without verbs) provide more "temporal specificity" (Zwaan, 1996: 1196), indicating temporal relations between events (Almeida, 1995; Zwaan, 1996), for instance, sequence (First I talked to my mother; then I called my brother) and chronological distance (It has been three years since I talked to my ex-boyfriend). In addition, adverbials can indicate the duration of an event (Almeida, 1995; Hasselgård, 2014; Klein, 2009b) or its frequency (Hasselgård, 2014; Klein, 2009b) or locate it on a calendric timeline (It was 2009; it all happened last February) (Almeida, 1995; Hasselgård, 2014; Klein, 2009b).

Classifications of adverbs and adverbials, sometimes called circumstantials and adjuncts, vary. To simplify, we used the term 
temporal adverbial broadly to refer to what Hasselgåard (2014) called time adjuncts (p. 25), which are single- or multi-word expressions that "locate events and states [and actions or activities] in time (sometimes in relation to other events) or specify their duration (I slept for twelve hours straight) or frequency (two or three times a week)" (p. 25). Temporal adverbials are syntactically and semantically heterogeneous in both English (Hasselgård, 2014) and Spanish (Bustos Gisbert, 2014), realized by a variety of forms, including single- and multi-word adverbs, prepositional phrases, noun phrases, and finite, nonfinite, and verbless clauses (Hasselgård, 2014: 37). Thus, for second-language learners the acquisition of temporality can be quite complex.

\subsection{Second language development of temporal expression}

Research on second-language (L2) acquisition of temporality has generally been either form-oriented or concept-oriented (Bardovi-Harlig, 1999, 2000). In form-oriented studies (e.g., Bardovi-Harlig, 1994; Comajoan, 1998; Long \& Sato, 1984; Salaberry, 2000), researchers typically investigate the stages of the acquisition of specific linguistic forms. For example, Salaberry (2000) identified five stages for the acquisition of the aspectual differences between the preterite (completed aspect) and imperfect (continuous aspect) tenses by L2 learners of Spanish. Initially, past tense morphology is not marked (Stage 0). Then, learners adopt the preterite as the default past-tense marker (Stage 1) regardless of aspect. In Stage 2 they begin to use the imperfect but only to express states like was and felt. In Stage 3, learners extend the use of the imperfect to verbs other than statives, such as arrived and built, but still often depend on inherent meanings of the verbs to make their aspectual choices. Finally, learners rely less on the semantic features of the verbs themselves and may mark any type of verb with imperfect or preterite morphology. 
In meaning-oriented studies (e.g., Ewert, 2006; Klein, 1994; Meisel, 1987; Trévise, 1987; Véronique, 1987), instead of focusing on the developmental order for specific linguistic forms, "the researcher examines the range of linguistic devices a speaker uses to express a particular concept" (Bardovi-Harlig, 1999: 347), for instance, temporality. Meaning-oriented studies extend beyond morphology, involving not only verbs but adverbials and discourse principles as well.

Some early concept-oriented studies concerning L2 acquisition of temporality appeared in Von Stutterheim and Klein (1987) and Dietrich et al. (1995). These longitudinal studies involved the oral production of untutored learners living in the country where the language they were acquiring was spoken. Jointly, the scholars in these volumes identified three main development stages for the acquisition of temporality: prebasic, basic, and beyond basic varieties.

In the prebasic stage, verbs (if used at all) are often uninflected or inflected inconsistently and are not marked for past tense. Temporality tends to be expressed lexically or by PNO. Typically, considerable extralinguistic information is needed to interpret temporality in the discourse produced by learners at this stage.

The next stage of development is the "basic variety" (Dietrich et al., 1995; Klein, 1994). At this stage verbs appear in their base form, but copulatives are still omitted. Use of various temporal adverbials, such as yesterday, often, Sunday, and before, increases with some ability to indicate time spans, to locate events on a timeline or in relation to one another, and to express duration and frequency.

In the third stage, "beyond the basic variety" (Klein, 1994, 1995; Von Stutterheim \& Klein, 1987), learners mark aspect and tense morphologically. Adverbial vocabulary continues to increase. At this stage learning is gradual but continuous, and initially, learners may use forms without a clear recognizable function. Tense marking precedes aspectual marking and irregular morphology appears before regular morphology. 
Researchers whose studies appear in Von Stutterheim and Klein (1987) and Dietrich et al. (1995) examined oral narratives. By contrast, Bardovi-Harlig (1992, 1994) studied written data, finding (1992) that the use of time adverbials by learners of English as a second language (ESL) seems to decrease as the use of past tense morphology increases. In a later study, also with ESL learners, Bardovi-Harlig (1994) reported that adverbials instead of verbal morphology may provide an early means for learners to present events out of sequence, what she called "reverse-order reports" (RORs). In other words, when learners deviate from PNO, they initially use time adverbials instead of the pluperfect to produce successful RORs.

Lubbers (2006), also working with written data, examined the ways English-speaking L2 learners of Spanish relate past events. She found that past verbal morphology increases with years of study, although the use of adverbs for past-temporal reference remains stable even with increased language proficiency. That is, for L2 learners of Spanish, past morphology does not replace adverbial use but instead develops in tandem with lexical devices.

Our concept-oriented study, in which we examined temporal expressions in personal narratives written by instructed learners of Spanish enrolled in a third-year college-level course, contributes to the scholarship on the acquisition of temporality. It takes a detailed look at the use of temporal expressions by a group of learners in the beyond-basic variety who have a developed but imperfect control of past tense morphology as shown by a previous study (Castañeda \& Carduner, 2013). The current study was guided by the following research questions (RQ):

RQ 1: What types of temporal meanings do learners of Spanish express apart from tense and aspectual information?

RQ 2: What lexical and syntactic resources do learners of Spanish use in addition to verb morphology to communicate temporality in personal narratives? 


\section{Methodology}

We took a concept-oriented approach to examining learners' use of temporal expressions in our corpus. Concept-oriented approaches are "valuable when examining the development of interlanguage because language learners may press any linguistic resource in their repertoire into service for a particular discursive function" (Ewert, 2006: 2). That is, instead of focusing on the employment of particular morphemes, structures, or vocabulary, or specific temporal meanings, we searched for all temporal indicators learners use, including those achieved by PNO. In addition, our approach may be considered corpus-driven instead of corpus-based (Granger, 2012) in that we did not test a hypothesis against the corpus, but used the corpus to derive an overall picture of what third-year learners' expressions of time look like in personal narratives written in Spanish.

\subsection{The corpus}

Learner corpus researchers may use an existing corpus or compile their own (Granger, 2012). As we were interested in a specific genre, namely personal narratives, written by a specific demographic - native English-speaking learners of Spanish enrolled in a third-year university Spanish course - we compiled our own. It consisted of 34 personal narratives of 700-900 words written by our target demographic. The essays, all first drafts submitted electronically through a course management system, were part of the course requirements for a 30 000-level university Spanish grammar and composition course at a medium-sized public Midwestern U. S. university, ${ }^{1}$ located in a small city with a population of 28904

1 Students enrolled in 30 000-level courses are in their sixth semester of college Spanish. They have been exposed to all major tenses and moods in Spanish and some connector words. They are learning to write descriptive essays, narrations, and short expository pieces in which they present and defend an opinion. 
(United Sates Census Bureau, 2010). At the time data were collected, according to the university fact book, the number of students reporting to be Hispanic or Latino was less than $3 \%$. In order to register for this course, students must have either completed two elementary and two intermediate Spanish courses at the university or tested into the course via a placement test. The assignment instructions specified that students were to write about a critical life experience or incident leading to a "lesson learned".

Initially, all essays $(n=55)$ submitted by students enrolled in the course between 2009 and 2011 were considered. It was assumed that students registered in the class, by virtue of having completed the previous courses or via placement testing, had been exposed via instruction to all verb tenses and moods in Spanish. In a previous study with the same corpus (Castañeda \& Carduner, 2013), the authors found that students had a developed but imperfect control of past tense morphology. As in the previous study just mentioned, four essays written by nonnative speakers of English were eliminated to ensure a more homogeneous sample, leaving 51 essays. Of these remaining 51 essays, two thirds $(n=34)$ formed the final corpus for this study. The other third ( $n=17)$ was excluded because students did not follow assignment instructions and failed to recount a critical incident leading to a lesson learned.

\subsection{Procedures}

Upon institutional review board (IRB) approval, we uploaded the essays as separate files to a password-protected, shared institutional workspace in Google Docs in order to annotate, code, and analyze each expression of temporality in its full discursive context (i.e., the entire essay). We later transferred the files to a commercial, password-protected, commercial Web-based corpus tool called Sketch Engine for further analysis, consistency checks, and data extraction. We coded and analyzed data in five phases: (a) data immersion and brainstorming, (b) initial coding, (c) focused coding, (d) final check for consistency within and across essays, and (e) 
tabulation of the codes. We proceeded iteratively instead of linearly as is common in qualitative research (Charmaz, 2014; Friedman, 2012; Saldaña, 2009; Tracy, 2013), refining our codes, recoding essays, and checking for consistency over several partial and three full cycles of coding.

In the data immersion and brainstorming phase, we worked separately, each reading and annotating half the essays (17 each). Using the font tools in Google Docs, we highlighted all references to time, including implicit ones, that we could locate and used the comments tool to record ideas for classifying and categorizing temporal expressions and to note other questions and impressions prompted by the essays.

Once we finished annotating the essays, we compared notes and devised a preliminary coding scheme. Our notes suggested coding temporal expressions along two dimensions: (a) by communicative function, such as chronological ordering of events, indicating duration or frequency; and (b) by grammatical form, for instance, single words, prepositional phrases, clauses, and PNO. Thus, we established a tentative two-code system to be piloted and refined during the next phase of our procedures: initial coding.

During initial coding we worked synchronously from separate locations, using the Blackboard IM call tool (voice chat) to converse as we coded collaboratively. We proceeded by taking turns reading the essays aloud. Whenever we encountered a segment in which temporality was expressed (other than those marked by ordinary verbal morphology), we highlighted the segment and included a code after the segment (Figure 1).

Cuando yo estaba una niñita, (6F) a mí me encanta a cocinar. Mi hermanita y yo siempre (4A) mirábamos el <<Food Channel > (una red de la televisión sobre el arte de cocinar). Un día (1A) fuéramos con nuestra mama para visitar nuestra abuela. Mama y Abuela hablaron en la cocina y $(2 \mathrm{H})$ mi hermanita y yo fuéramos al piso arriba para jugar y mirar el Food Channel

Figure 1. Example of initial coding

Our goals in the initial-coding phase were to test our coding scheme, modify it as needed by the data, and construct a codebook or "data 
display that list[ed] key codes, definitions and examples" to be used for analysis (Tracy, 2013: 190). As we coded, we used the comments tool in Google Docs to make analytical memos (Saldaña, 2009: 32) with respect to coding difficulties and decisions made. In instances of disagreement, we discussed our respective rationales, consulted previously coded essays, and summarized our discussion and decision with the comments tool. Because initial codes were provisional (Charmaz, 2014), at this stage we remained "open to other analytic possibilities" (117) by not forcing codes onto our data. We simply highlighted and took notes on instances of temporality that did not fit our initial codes and returned to them in later rounds after our coding scheme had been refined.

Using constant comparative techniques (Charmaz, 2014), we modified our coding scheme several times, splitting and lumping (Saldaña, 2009; Tracy, 2013) and relabeling the categories as warranted by the data, and taking into account terminology used in prior research on temporality. After each substantial change, we coded the essays anew, repeating this process until we were satisfied that our coding scheme could account for every token in our corpus. We created a coding grid for quick reference (Table 1) and a detailed codebook with definitions and examples from the corpus (Appendices A \& B) to ensure coding consistency.

During focused coding, we used procedures similar to those used during initial coding; that is, we worked synchronously via Blackboard Call, again taking turns reading the essays aloud and using special fonts and comments to code the data and document our decisions. In this stage, our goal was to check the accuracy of our final iteration of initial coding against our codebook and correct any errors or omissions in the previously processed essays. At this point, we made no more changes to our codebook. We simply confirmed that the codes we assigned to each expression were consistent and made corrections as necessary. Once completed, we uploaded the essays to Sketch Engine to begin the final step in our coding process: consistency verification. 
Table 1. Two-dimensional coding grid by form and function

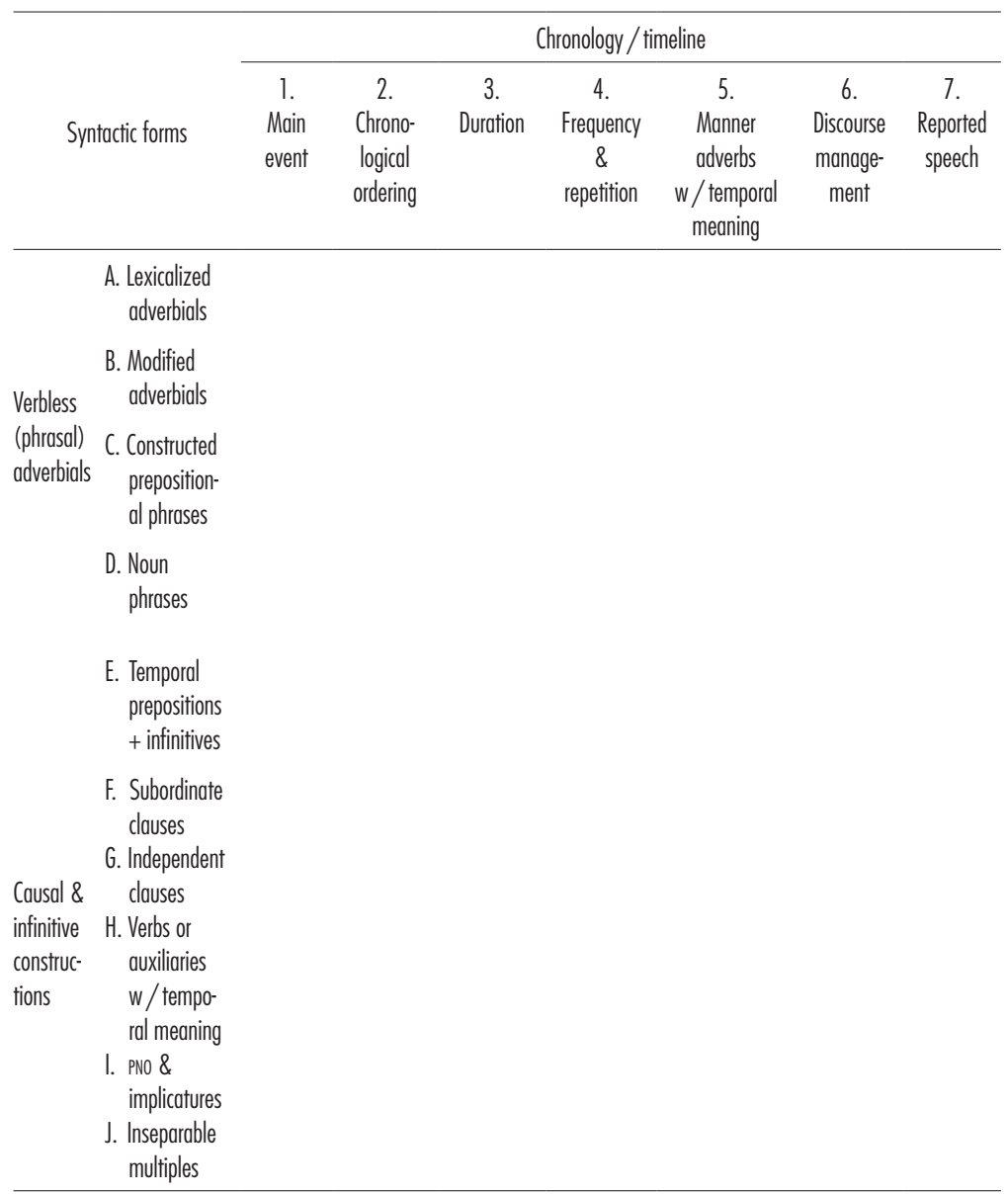

We met in person to perform the final consistency check and to tabulate the codes. We used the word list tool in Sketch Engine to identify and sort every temporal expression in the corpus according to its assigned code. We used the keyword in context (KWIC) (Figure 2) and expanded concordance (Figure 3) tools to compare coding both within and across essays. The metadata provided by 
Sketch Engine enabled us to locate essays containing any token whose code we needed to revise. We performed consistency checks for every single coded item in our corpus. Once all coded tokens were verified or corrected as needed, we again uploaded the coded essays to Sketch Engine and used the word list frequency count to tabulate our data.

File\#5 “. (6aJ) Todos cambiaron en el 27 de febrero. ( IA ) Estuve a la casa de mi novio cuando mi padre me
File\#5 hasta ella se mejore. (6dG) En este momento, ( IA ) todos cambiaron
File\#9 ,ellos se de alto parte de Michigan. Algún día ( IA ) , mi papá estaba enfermo, pero él fue a
File\#9 (6bG). Yo perdió mi mejor amigo en este día ( IA )
File\#10 tocaba ocho horas. (7J) Recuerdo éste día ( IA ) porque del sol de colores magníficos
* For our coding system 1, 2, 3, etc. refers to type of temporal expression or usage, and the capital letter, A, B, C,
etc. refers to the grammatical shape. Specifically, Code 1A indicates that the expression is used to identify a main
event in the narrative and A indicates it is a fixed adverbial expression.

Figure 2. Sample concordance for expressions marked with code $1 A^{*}$

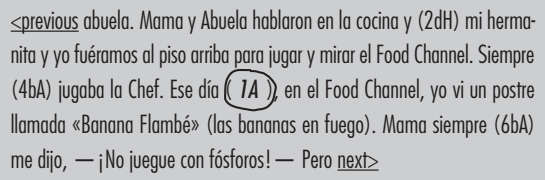

Figure 3. Sample of an expanded concordance

\section{Results}

Researchers must choose the level of detail with which to code (Saldaña, 2009; Tracy, 2013). To be thorough, we coded every token of temporal expression encountered, including those that occurred in reported speech. Following Bardovi-Harlig (1995, 1998), however, we later excluded from our tally and analysis those tokens that appeared in reported dialogue, so as to avoid skewing results with temporal expressions that were essentially parenthetical and not used to advance the plot of the narrative. For example, one student, narrating an incident with the police, wrote "El 
gritó-iSiéntate en la tierra, ahora!" We did not count the word ahora in the analysis presented here. A precedent exists for omitting segments of direct discourse (Bardovi-Harlig, 1995, 1998). In addition, we tracked but did not count in our tabulations or results polysemous words that are only sometimes used to express time when context suggested a nontemporal usage (see example in Appendix A, Code 8). Our overall findings appear in Table 2. Because this is a qualitative study, results are presented using descriptive statistics rather than inferential statistics. Excerpts from the corpus exemplify typical usage employed by the participant students.

TABlE 2. Overall distribution of the forms and functions of temporal expressions

\begin{tabular}{|c|c|c|c|c|c|c|c|}
\hline \multirow[b]{2}{*}{ Syntax } & \multicolumn{6}{|c|}{ Chronology } & \multirow[b]{2}{*}{ Total } \\
\hline & $\begin{array}{c}\text { (1) } \\
\text { Main } \\
\text { Event }\end{array}$ & $\begin{array}{c}\text { (2) } \\
\text { Ordering } \\
\text { of events }\end{array}$ & $\begin{array}{c}\text { (3) } \\
\text { Duration }\end{array}$ & $\begin{array}{c}\text { (4) } \\
\text { Frequency / } \\
\text { repetition }\end{array}$ & $\begin{array}{c}(5) \\
\text { Manner } \\
\text { w/time }\end{array}$ & $\begin{array}{c}\text { (6) } \\
\text { Discourse } \\
\text { management }\end{array}$ & \\
\hline $\begin{array}{l}\text { A. Lexicalized } \\
\text { expressions }\end{array}$ & 21 & 98 & 16 & 52 & 26 & 141 & 354 \\
\hline $\begin{array}{l}\text { B. Modified } \\
\text { adverbials }\end{array}$ & - & 12 & 4 & 5 & 5 & 4 & 30 \\
\hline $\begin{array}{l}\text { C. Prepositional } \\
\text { phrases }\end{array}$ & 5 & 27 & 15 & 3 & 3 & 21 & 74 \\
\hline $\begin{array}{l}\text { D. Noun } \\
\text { phrases }\end{array}$ & 43 & 9 & - & 1 & - & 17 & 70 \\
\hline $\begin{array}{l}\text { E. Prepositions } \\
+ \text { infinitive }\end{array}$ & - & 11 & - & - & $\cdot$ & 3 & 14 \\
\hline $\begin{array}{l}\text { F. Subordinate } \\
\text { clauses }\end{array}$ & 4 & 93 & $\cdot$ & 8 & 1 & 33 & 139 \\
\hline $\begin{array}{l}\text { G. Independent } \\
\text { clauses }\end{array}$ & 4 & 10 & 1 & 2 & $\cdot$ & 40 & 57 \\
\hline $\begin{array}{l}\text { H. Temporal } \\
\text { verbs }\end{array}$ & - & 25 & - & 4 & 1 & 12 & 42 \\
\hline I. Implicature & - & 599 & - & - & $\cdot$ & 6 & 605 \\
\hline J. Multiples & 21 & 141 & 3 & 12 & $\cdot$ & 161 & 338 \\
\hline Total & 98 & 1025 & 39 & 87 & 36 & 438 & 1723 \\
\hline
\end{tabular}


Excluding tokens employed in reported speech and polysemous words whose function was not temporal, we identified a total of 1723 temporality markers in the essays. In the following analyses, first by function and then by form, we examine patterns of temporal expression employed by the learners.

\subsection{Function of temporal expressions}

Relaying the chronology of events in the narrative was the most prevalent function for temporal expressions. Chronological information fell into three categories: (a) establishing or refining the primary time frame (1) for the main event of the narrative $(n=98)$, (b) indicating the chronological relationship (e.g., simultaneity (2), sequentiality (3), or temporal distance (4)) between two or more events, states, or activities $(n=1025)$, or (c) indicating their duration (5) $(n=39)$. Together, these three functions associated with the narrative's chronology (Codes 1 to 3 combined) represented $67.4 \%(n=1162)$ of the total tokens.

(1) El 19 del augusto, 2007 era el día que mi vida cambió para siempre. 'The 19th of august 2007 was the day that my life changed forever'.

(2) Mientras mezclaba el relleno, el timbre sonó.

'While I was mixing the filling the doorbell rang'.

(3) Oí la fiesta antes de mirarlo.

'I heard the party before I saw it'.

(4) La mañana antes, mi padre me había dado dos cientos dólares para gastar de ropa.

'The previous morning, my father had given me two hundred dollars to spend on clothing'.

(5) Ellos me regañaron por media hora.

'They scolded me for half an hour'. 
Using time words for discourse management was the second most prominent functional use of time expressions $(n=438)$. On a lexical or semantic level these segments looked like expressions of time, but on a pragmatic level they served primarily to organize the discourse and only secondarily to reference time. Example (6) contains several words that are lexically related to time; however, the writer's primary purpose for including these sentences was to tell what the story was going to be about, that is, to provide an abstract (Labov, 1972; Labov \& Waletzky, 1967) and set an emotional tone.

(6) Cuando están jóvenes, todos los niños sueñan con el día que les obtengan sus permisos de conducir. Es un momento en su vida que no olvidará.

'When they are young, all children dream about the day they get their drivers' licenses. It is a moment in their life that they will not forget'.

Finally, temporal markers of frequency and manner were rarely used. A mere 5\% $(n=87)$ of the total tokens denoted definite (7) or indefinite frequency $(8)$, and only $2 \%(n=36)$ of the tokens were temporal adverbs of manner (9).

(7) Alguien le tiró dos veces.

'Someone shot him two times'.

(8) Con frecuencia pensaba a visitar a mi primera familia de acogida en Honduras.

'I frequently thought about visiting my first host family in Honduras'.

(9) La montana rusa volteó muy rápidamente.

'The roller coaster turned very quickly'. 


\subsection{Syntactic form}

In terms of form, we found four main structural patterns. The first set included lexical or phrasal expressions that did not contain a verb (Codes A-D) including, respectively, lexicalized prepositional phrases (10), prepositional phrases modified with another adverbial (11), constructed prepositional phrases (12), and noun phrases without prepositions (13).

(10) Por la mañana vi el abogado.

'In the morning I saw the lawyer'.

(11) Unos 45 minutos más tarde, vimos luces de rojos y azules a muy lejos.

'About 45 minutes later, we saw some red and blue lights at the distance'.

(12) Era nerviosa como una niña en su primer día de escuela.

'She was nervous as a child on her first day of school'.

(13) Pensé sobre este cumpleaños horroroso.

'I thought about this horrifying birthday'.

Next, grouped collectively, were expressions of time containing verbs (Codes $\mathrm{E}-\mathrm{H})$, such as temporal prepositions with infinitives (14), subordinate clauses headed by a temporal conjunction (15), independent clauses with overall temporal meaning (16), and clauses headed by a verb or an auxiliary verb with temporal meaning (17).

(14) Después de comer, nosotras montamos tres atracciones.

'After eating, we rode three attractions'.

(15) Ella lloró cuando vio el coche.

'She cried when she saw the car'. 
(16) Fue invierno.

'It was winter'.

(17) Comencé a llorar.

'I started to cry'.

The third structural pattern included those segments in which temporal ordering was implied by the order of presentation, that is, by the principle of natural order (PNO) and the use of conventional implicature (Grice, 1975) resulting from the conjunction $y$. Example (18) illustrates how a learner communicated temporal sequentiality of four actions that happened in close temporal proximity without the use of additional temporal markers.

(18) Inserté la tarjeta y entré los números personales. Los botones aparecieron en la pantalla y escogí retirada.

'I inserted the card and entered the password. The buttons appeared on the screen and I chose withdrawal'.

The fourth structural pattern (Code J) comprised segments with syntactically or semantically inseparable, multiple expressions of time. In (19) tiempo and cuando are bound together since tiempo is the subject of the clause starting with the conjunction cuando. This example also contains a non-essential, pragmatic temporal word finalmente [finally], which communicates impatience at a wait. It also contains the verb esperar [wait], which contains, as part of its lexical meaning, the passage of time.

(19) Cuando el tiempo designado finalmente llegó fui a la biblioteca y esperé por Alyx.

'When the designated time finally arrived I went to the library and waited for Alyx'.

With 605 instances or $35.1 \%$ of the total tokens, implicature or PNO (18) was clearly the dominant strategy for expressing time. 
At 30.6\% ( $n=528)$ combined, verbless phrasal expressions were the second most common structure. Of these phrasal expressions, lexicalized adverbials or fixed expressions (10) were by far the most common at $20.5 \%$, followed by nonlexicalized or constructed prepositional phrases (12) at $4.3 \%$, noun phrases (13) at $4 \%$, and modified adverbials (11) at only a mere $1.7 \%$ of the total tokens.

Even combined, explicit temporal expressions with verbs (Codes E-H, $n=252$ ) were used less than half as often as PNO or phrasal expressions, representing only $14.6 \%$ of the total syntactic forms found in the corpus. Of these, subordinate clauses (15) represented only $8 \%$ of the temporal expressions in the data; clauses with verbs semantically related to time (17) appeared in only $2.4 \%$ of the instances; independent clauses (16) constituted 3.3\% of the data; and at only $.8 \%$, reduced clauses with time prepositions followed by an infinitive (14) were the least frequent syntactic form for expressing temporality in the entire corpus.

In addition to using implicature, phrases, and clauses to express time, students also produced 338 tokens containing multiple expressions of time within a single, inseparable unit (19). Structures of this type accounted for nearly one fifth $(19.6 \%)$ of the time markers in the corpus.

\section{Discussion}

In this section, the results will be discussed in terms of the research questions. That is, we first consider the functions of temporal expressions employed by our participants and then discuss syntactic patterns.

\subsection{Function of temporal expressions}

Since our goal was to examine the distribution of temporality in personal narratives at the discourse level, we use Labov (1972) and Labov and Waletzky's (1967) narrative framework as our starting point for the discussion. Although various temporal functions ap- 
peared in all segments of the narratives, expressions relating to chronology (Codes 1 to 3 ) were common in the orientation and were predominant in the complicating action and resolution. Temporal expressions, whose primary purpose was to organize the discourse (Code 6), tended to occur mostly in the abstract, evaluations, and codas, but sometimes also in the resolution. Frequency and repetition markers and temporal adverbs of manner were too rare to find distributional patterns by narrative segment. We begin with expressions relating to chronology, which taken together represented $67.4 \%(n=1162)$ of the total tokens.

All 34 essays contained an orientation that places the story in context in terms of setting, place, characters, and time. The writer in (20) used a series of chronological markers to establish the primary time frame for her narrative, transporting the reader to a specific point in her lifetime: just before she was about to turn eight years old. Calendric phrases like en abril [in April] were common.

(20) Le fue el primer día que hacía buen tiempo; fue un día soleado en abril y un mes antes de mi cumpleaños octavo.

'It was the first day that the weather was good; it was a sunny day in April and a month before my eighth birthday'.

The body or plot of a narrative typically comprises a "series of time ordered sequenced events" (Whitworth et al., 2015: 460), leading up to a climax, or high point. Example (21) illustrates how one participant, who got into trouble for ignoring her mother, related the events leading up to a punishment that occurs later in the story. The events are presented primarily implicitly through PNO enhanced with temporal markers to signify time gaps between events or to emphasize temporality.

(21) Se cayó? Contésteme! — dijo mi madre con pánico en su voz. Estuve la rebelión que yo fui, no contesté. Me burlé su desesperado mensaje y continué divertirme. Minutos después, escuché el familiar pitido y su voz de nuevo - esta vez, no fue asunto, fue enfado. 
Aún intenté permanecer tranquilla, lo ignoré otra vez. Menos de cinco minutos había pasado y escuchamos hojas crujido y pasos. 'Did you fall? Answer me", said my mother with panic in her voice. Being the rebel that I was, I didn't answer. I made fun of her desperate message and I continued to have fun. Minutes later, I heard the familiar whistle and her voice again-this time she wasn't frightened, she was mad. Still I tried to remain calm, $I$ ignored it again. Less than five minutes had passed and we heard leaves creaking and steps'.

Resolutions, like orientation and complicating actions, also contained multiple time expressions that communicated a sequencing of events. All 34 essays contained a resolution or outcome to the stories. Example (22) shows how one writer relates a sequential series of actions leading up to a solution for a failed attempt to cook for her friends. This participant (22) brings her story to a close with a combination of implicit and explicit sequencing indicators.

(22) Obviamente, la cena que planeé con cuidado no existió. Llamé "Craft Pizza"" para socorrerme. Mientras James salió para sacar las pizzas, mis amigos fenomenales limpiaron conmigo. Cuando James y las pizzas volvieron, sentamos en los sofás y comenzamos nuestra noche. La cena formal con un vino fino cambió a una cena típica de la pizza y la cerveza.

'Obviously, the dinner that I planned with care didn't exist. I called "Craft Pizza" to help me. While James left to get the pizzas, my phenomenal friends cleaned up with me. When James and the pizzas returned, we sat on the sofas and we began our night. The formal dinner with fine wine turned into a typical dinner of pizza and beer'.

The second most frequent usage of time words (438 tokens or $25.4 \%$ of the total tokens) was not to organize happenings along a

2 Pseudonyms have been substituted for personal names and names of organizations. 
timeline but to organize the discourse itself and enrich the narrative with emotional markers and commentary or evaluations. Although these expressions often communicated some temporality, the primary function was something other than placing events, states, and activities on a timeline. Temporal markers of this type were common in the abstract, evaluations, and coda.

Abstracts, which are optional, present a summary of what a narrative will be about (Eggins \& Slade, 1997). Slightly more than a third of the essays ( $n=13$ ) contained one. These served mainly to establish the topic or to engage the reader with the topic by appealing to shared cultural experiences or common emotions. Example (23) illustrates a typical abstract. Here cuando están jovenes and es un momento en su vida are both used to make generalizations, communicate the topic of the essay, and draw the reader into the story rather than communicate chronology.

(23) Cuando están jóvenes, todos los niños sueñan con el día que les obtengan sus permisos de conducir. Es un momento en su vida que nunca olvidará.

'When they are young, every child dreams about the day they will obtain their driver's license. It is a moment in their life they will never forget'.

Discourse management markers were common in evaluations as well. Evaluations, which are expressions of emotion, emphasis, perspective, and insight, are "the core of personal narratives because they convey the significance of the event for the teller [...] and are critical for a narrative to be coherent" (Reese et al., 2011: 429). Evaluations may appear anywhere in a narrative. All 34 essays contained abundant evaluations distributed throughout the texts. These evaluations frequently contained temporal words, whose primary function was discursive instead of temporal as illustrated in (24), in which the writer used time words to make a generalization and to foreshadow an accident with fireworks. 
(24) Cuando una persona juege con algun muy peligro, Ud. no debe oir el consejo de un otra persona, quien no tiene una cautela.

'When a person plays with something dangerous, he should not listen to the advice of someone who is not cautious'.

Codas, the other section with many discourse organizers communicated with time words, bring the reader back to the present time. They are optional; however, the majority of the essays ( $n=26$ or $76.5 \%$ ) contained one, potentially because assignment instructions emphasized that the lesson learned should be clear to the reader. Example (25) illustrates how the writer, who got into trouble for grabbing pumpkins from the neighbors' houses and smashing them on the street, reflects on his past behaviors and playfully draws the reader back into the present, even directly addressing the reader. The example shows that, once again, time words were often used to organize and enrich the discourse and not simply to organize events temporally along a timeline. The time words in this segment are used to recap and summarize the point of the story.

(25) No obstante, aprendí de mis faltas y nunca se metí en problemas otra vez. Quizás ha aprendido la lección, o quizás no nunca agarré otra vez. ¡Eso es para mi saber, y para tú averiguar!

'Nevertheless, I learned from my errors and I never got in trouble again. Maybe I have learned my lesson or maybe I will never grab again. This is for me to know and for you to find out'.

In addition to genre, assignment instructions may have influenced the distribution of temporal expressions by function. Students were instructed to engage the reader emotionally by using intensifiers or hyperbole, introspection, humor, reported speech, foreshadowing, and summary of the lesson learned. Many of these contained temporal expressions predominantly occurring in the discourse management category. In other words, assignment instructions may have prompted students to be particularly attentive to rhetorical 
strategies for effective storytelling which, in turn, may have increased the quantity and variety of temporal expressions employed.

\subsection{Syntax of temporal expressions}

As with function of temporal expressions, genre appears to be the most important factor in the choice of syntactic forms. Proficiency level may have also influenced the choice of syntactic forms, but perhaps to a lesser degree than genre. With 605 tokens, the PNO or implicature was the most frequent means of indicating chronology. Example (26), with four instances of PNO, illustrates its use by one of our participants, who presents a series of events leading up to getting caught shoplifting.

(26) Hace dos horas, habíamos gastado todo nuestro dinero. Diana había escondido todo nuestro joyas robados en un bolsilla escondido adentro de su bolsa. Teníamos mucho cuidado. En un centro comercial como eso, las cameras en las paredes vieron todos nuestros acciones. (PNO) Caminamos al final pasillo del centro y (PNO) $d e-$ cidimos a entrar uno tienda más antes de volver a la casa. (PNO) Entramos Accessories Store, una tienda pequeña que vende joyas. Por este momento, tuvimos mucho sueño y habíamos perdido mucho concentración. (PNO) Decidí no robar nada en esta tienda, fue demasiada cansada.

'After two hours we had spent all of our money. Diana had hidden our stolen jewels in a hidden pocket in her purse. We were very careful. In a mall like that, the cameras in the wall saw all our actions. We (PNO) walked to the end of the hallway of the mall and we (PNO) decided to enter one more store before returning home. (PNO) We entered Accessories Store, a small store that sells jewelry. By this time, we were tired and we had lost a lot of concentration. (PNO) I decided to not steal anything in this store, I was too exhausted'. 
PNO is one of the earliest strategies second language learners use to express temporality. It is the "simplest way for speakers and writers to express the temporal relation between successive actions or events" (Bestgen \& Costermans, 1997: 204). Because prebasic varieties are characterized by heavy use of PNO, one might be tempted to conclude that the participants in our corpus, having employed PNO so frequently, were at an early stage of development in their ability to express time in narratives; however, this was not the case. As (26) and many of the other examples above illustrate, texts produced by the participants contained verbs inflected with past morphology, albeit not always accurately. The use of past morphology does not appear until the beyond basic stage.

All participants in this study had emerging but variable control of past morphology, as reported previously (Castañeda \& Carduner, 2013). In other words, they were all beyond the basic stage, suggesting that genre, not lack of proficiency, might account for the high use of PNO, which occurs naturally in narratives and is not used solely by language learners (Bardovi-Harlig, 1994). In fact, chronological order is so central that some linguistic definitions of narrative are defined by the presence of PNO (Bardovi-Harlig, 1994).

Phrasal adverbs and adverbials, at $30.6 \%(n=528)$, were the second most frequent syntactic group of temporal expressions and, among these, lexicalized adverbs and adverbials dominated $(n=354)$. Since lexicalized adverbials emerge during the prebasic phase, one might assume that high use indicates lower proficiency; however, the use of past tense morphology again indicates that the participants are not using these phrases to substitute verb forms but to complement them, paralleling findings by Lubbers (2006). Example (26), discussed above, contains three phrasal adverbials, hace dos horas, antes de volver a casa, and por este momento, distributed across the text at strategic points, to give coherence to the narrative.

Clausal expressions (Codes E-H combined) were used with less frequency ( $n=252$ or $14.6 \%$ ) than PNO or phrasal adverbials; 
however, these results should be interpreted cautiously because PNO structures were all sentences or contained independent clauses as well. Participants are clearly able to produce clauses, yet the smaller number of temporal prepositions with infinitives and subordinate clauses may suggest some proficiency constraints or avoidance. Students may not yet have mastered structural differences in English and Spanish with regard to subordination.

In English, temporal prepositions are followed by a gerund, whereas in Spanish the infinitive is used. By the third year of university instruction, participants will have been taught this distinction but may not yet be comfortable using the structure. Some of the learners use temporal prepositions with infinitives correctly as in (14) above, whereas others still seem to transfer the gerund form from English (27).

(27) *Después de cortando la lechuga, todo fue un desastre!

'After cutting the lettuce, everything was a disaster!'

In the case of subordinate clauses, these are formed with a temporal conjunction. Verbs in both clauses must be conjugated, and in the subordinate clause the writer may have to choose between an indicative or subjunctive form in addition to deciding on tense. The most common temporal conjunctions employed were cuando [when], mientras [while] and antes de que [before]. Morphosyntactic errors were evident in many of the attempts to antes de que as a conjunction as in (28), which illustrates both the failure to include the word que and wrong choice of mood. The student used an indicative form instead of the required subjunctive.

(28) *Antes de mis padres salieron, se preguntaron me hablar de las reglas.

'Before my parents left, they asked me to talk about the rules'.

Accounting for $19.6 \%$ of the structures used, we coded 338 units with multiple expressions of time like (19) above. Among these, 
we encountered inseparable combinations of various syntactic types: temporal phrases combined with clauses, clauses and phrases containing temporal verbs combined with adverbs and conjunctions, and so forth. Were the units separable, some syntactic categories may have had higher counts; therefore, we must exercise caution in drawing firm conclusions about the distribution of syntactic patterns.

\section{Conclusion}

Our study is qualitative and, therefore, not exempt from the limitations of such methods; however, we rigorously followed best practices recommended by experts on qualitative research as detailed in the methods section. Despite limitations, results indicate that participants employed a wide range of temporal expressions in terms of function and form when narrating; however, certain forms and functions were more prevalent than others. Iterative examination of the temporal expressions in their full discursive context combined with comparisons of coded segments across essays via the concordance tool in Sketch Engine suggests that genre was the most important factor in determining how participants communicated temporality. This may have been reinforced by assignment instructions, which specified that students engage their reader through various rhetorical devices, some of which might include temporal markers. Proficiency may have played a role in the participants' use of temporal expressions; however, because the writers were beyond the basic level, proficiency limitations seemed to play a lesser role than genre.

Research on how learners encode time when narrating has often focused on morphological marking of tense and aspect, to the exclusion of other devices. Moreover, early researchers on temporality primarily examined oral narratives, often with uninstructed learners. Although prior research has made an undeniably valuable contribution, we need to know more about the strengths and lim- 
itations of instructed learners - with written discourse as well as oral discourse. That knowledge must extend beyond morphology. Our study reinforces the need to shed the "inflectional paradigm bias" (Klein, 1995: 17-18) when assessing learners' ability to express temporality. A focus on morphological accuracy alone may lead to underestimate learners' ability to communicate temporal meaning or misjudge their proficiency level. Our concept-oriented approach reveals that students were able to tell their stories quite effectively, using temporal words, phrases, and clauses despite imperfect (but developing) control of verbal morphology. This is not to minimize the importance of morphology but to urge scholars and instructors not to ignore the other devices for expressing time. Temporal reference is achieved via a complex interplay of lexical, morphological, syntactic, and pragmatic devices (Klein et al., 1993). In narratives, temporality is central. Because genre appears to be a key factor in learners' choice of temporal markers, inducing them to produce many and varied temporal expressions, instructors may want to take advantage of their students' familiarity with the narrative genre to promote the continued development of temporality.

Moreover, the role of genre in relation to the distribution of temporal markers confirms the need to examine learner language at the discourse level. By conducting multiple readings of students' entire essays, we discovered that students use temporal expressions not only to express temporality but also to organize their text, to engage the reader, and to reflect on the meaning of their narrative. Had assessment of students' development of temporality been conducted at the sentence level or removed from its discursive context, these rhetorical skills may have been overlooked. Our findings suggest that more concept-oriented studies using original texts produced by language learners are needed to complement form-oriented studies. Our study focused on the variety, distribution, and function of temporal expressions. A future study might examine how these expressions that point to time co-occur with the tense, mood, and aspectual marking of the verbs employed by language 
learners, as done by Granda (2010). Also, research on temporality employed with other genres as well as with narratives about other topics with instructed learners at various stages in their program and in other languages can provide further insights into the development of temporality.

\section{References}

American Council of the Teaching of Foreign Languages (AcTFL) (2012). ACTFL: Proficiency guidelines: Writing. http://www.actfl.org

Allison, John M. (1994). Narrative and time: A phenomenological reconsideration. Test and Performance Quarterly, 14(2), 108-125.

Almeida, Michael J. (1995). Time in narratives. In Judith F. Duchan, Gail A. Bruder, \& Lynee E. Hewitt (Eds.), Deixis in narrative: A cognitive science perspective (pp. 159-189). Hillsdale: Erlbaum.

Bardovi-Harlig, Kathleen (1992). The use of adverbials and natural order in the development of temporal expression. International Review of Applied Linguistics and Language Teaching, 30(4), 299-320.

Bardovi-Harlig, Kathleen (1994). Reverse-order reports and the acquisition of tense: Beyond the principle of chronological order. Language Learning, 44(2), 243-282.

BardoviHarlig, Kathleen (1995). A narrative perspective on the development of the tense/aspect system in second language acquisition. Studies in Second Language Acquisition, 17(2), 263-291.

Bardovi-Harlig, Kathleen (1998). Narrative structure and lexical aspect: Conspiring factors in second language acquisition of tense-aspect morphology.

Studies in Second Language Acquisition, 20(4), 471-508.

Bardovi-Harlig, Kathleen (1999). From morphemes studies to temporal semantics:

Tense-aspect research in SLA. Studies in Second Language Acquisition, 21(3), 341-382.

Bardovi-Harlig, Kathleen (2000). Tense and aspect in second language acquisition:

Form, meaning and use. Malden: Blackwell.

Bardovi-Harlig, Kathleen (2013). Research design: From text to task. In Rafael

Salaberry \& Llorenc, Comajoan (Eds.), Research design and meth- 
odology in studies on L2 ttense and aspect (pp. 219-269). Berlin:

Walter de Gruyter.

Bestgen, Yves, \& Costermans, Jean (1997). Temporal markers of narrative structure:

Studies in production. In Jean Costermans \& Michael Fayol (Eds.),

Processing interclausal relationships: Studies in the production and comprehension of text (pp. 201-220). Mahwah: Lawrence Erlbaum. Bestgen, Yves, \& Piérard, Sophie (2008). Use of temporal adverbials as segmentation discourse markers by second language learners. Archives de Psychologie, 73, 209-230.

Bustos Gisbert, José Manuel (2014). Conexión temporal y conectores temporales en textos narrativos. Lingüística Española Actual, 36(1), 35-73. Castañeda, Daniel, \& Carduner, Jessie (2013). Patterns of past tense production by third-year students of Spanish: A discourse analysis of open-ended personal narratives. Estudios de Lingüística Aplicada, 31(58), 77-99.

Charmaz, Kathy (2014). Constructing grounded theory (2nd ed.). Thousand Oaks: Sage.

Comajoan, Llorenç (1998). The acquisition of past morphology in Catalan as a foreign language: Interaction of lexical aspect and discourse grounding in the L2 acquisition of past morphology of Catalan. Paper presented at the Second Language Research Forum, Manoa, Hawai'i.

Council of Europe (2001). Common European framework of reference for languages: Learning, teaching, assessment. Cambridge: Cambridge University Press.

Dietrich, Rainer; Klein, Wolfgang, \& Noyau, Colette (Eds.) (1995). The acquisition of temporality in a second language. Amsterdam: John Benjamins.

Eggins, Suzanne, \& Slade, Diana (1997). Analysing casual conversations. London: Cassell.

Ewert, Doreen Elizabeth (2006). The expression of temporality in the written discourse of L2 learners of English: Distinguishing text-types and text passages [Unpublished doctoral dissertation]. Indiana University, Bloomington. 
Fernández Rodríguez-Escalona, Guillermo (2009). Los sintagmas nominales como determinadores temporales del enunciado en español. Linguistica Pragensia, 19(1), 36-49.

Friedman, Debra A. (2012). How to collect and analyze qualitative data. In Allison Mackey \& Susan M. Gass (Eds.), Research methods in second language acquisition: A practical guide (pp. 180-200). Malden: Wiley-Blackwell.

Granda Dahan, Beatriz G. (2010). Análisis del dominio de la expresión de la temporalidad en la narrativa en español como L2 [Unpublished doctoral dissertation]. Universidad Nacional Autónoma de México, Mexico. Granger, Sylviane (2012). How to use foreign and second language corpora. In Allison Mackey \& Susan M. Gass (Eds.), Research methods in second language acquisition: A practical guide (pp. 7-29). Malden: Wiley-Blackwell.

Grice, Herbert Paul (1975). Logic and conversation. In Peter Cole \& Jerry L.

Morgan (Eds.), Syntax and semantics (Vol. 3, pp. 41-58). New York:

Academic Press.

Hasselgård, Hilde (2014). Adjunct adverbials in English. Cambridge: Cambridge University Press.

Hickmann, Maya, \& Hendriks, Henriëtte (2015). Time talk in narrative discourse:

Evidence from child and adult language acquisition. In Jacqueline

Guéron (Ed.), Sentence and discourse (pp. 92-120). Oxford: Oxford University Press.

Klein, Wolfgang (1994). Time in language. London: Routledge.

Klein, Wolfgang (1995). Frame of analysis. In Rainer Dietrich, Wolfgang Klein

\& Colette Noyau (Eds.), The acquisition of temporality in a second language (pp. 17-29). Amsterdam: Benjamins.

Klein, Wolfgang (2009a). Concepts of time. In Wolfgang Klein \& Ping Li (Eds.),

The expression of time (pp. 5-38). Berlin: Mouton de Gruyter.

Klein, Wolfgang (2009b). How time is encoded. In Wolfgang Klein \& Ping

Li (Eds.), The expression of time (pp. 39-82). Berlin: Mouton de Gruyter.

Klein, Wolfgang; Dietrich, Rainer, \& Noyau, Colette (1993). The acquisition of temporality. In Clive Perdue (Ed.), Adult language acquisition: Cross-lin- 
guistic perspectives: Vol. 2 The results (pp. 73-118). Cambridge: Cambridge University Press.

Labov, William (1972). Language in the inner city: Studies in the black English vernacular. Philadelphia: University of Pennsylvania Press.

Labov, William, \& Waletzky, Joshua (1967). Narrative analysis: Oral versions of personal experience. In June Helm (Ed.), Essays on the verbal and visual arts: Proceedings of the 1966 Annual Spring Meeting of the American Ethnological Society (pp. 12-44). Seattle: University of Washington Press.

Long, Margaret N., \& Sato, Christine (1984). Methodological issues in interlanguage studies: An interactionist perspective. In Alan Davies, Clive Criper, \& Anthony P. R. Howatt (Eds.), Interlanguage (pp. 253-279). Edinburgh: Edinburgh University Press.

López Ortega, Nuria R. (2000). Tense, aspect and narrative structure in Spanish as a second language. Hispania, 83(3), 488-502.

Lubbers Quesada, Margaret (2006). L2 acquisition of temporal reference in Spanish and the interaction of adverbials, morphology and clause structure. In Nuria Sagarra \& Almedia Jacqueline Toribio (Eds.), Selected proceedings of the 9th Hispanic Linguistics Symposium (pp. 157168). Somerville: Cascadilla Proceedings Project.

Meisel, Jürgen M. (1987). Reference to past events and actions in the development of natural second language acquisition. In Carol Wollman Pfaff (Ed.), First and second language acquisition processes (pp. 206-224). Rowley: Newbury House.

Méndez García de Paredes, Elena (1990). Tiempo verbal y subordinación temporal: la relación de simultaneidad. In Alexandre Veiga \& Gerd Wotjak (Eds.), La descripción del verbo español (pp. 207-220). Santiago de Compostela: University of Santiago de Compostela.

Morency, Patrick (2015). When temporal expressions do not tell time: A pragmatic approach to temporality, argumentation and discourse [Unpublished doctoral dissertation]. University of Neuchâtel, Switzerland. Reese, Elaine; Haden, Catherine A.; Baker-Ward, Lynne; Bauer, Patricia; Fivush, Robyn, \& Ornstein, Peter A. (2011). Coherence of personal narratives across the lifespan: A multidimensional model and coding method. Journal of Cognition and Development, 12(4), 424-462. 
Salaberry, M. Rafael (2000). The development of past tense morphology in L2 Spanish. Amsterdam: John Benjamins.

Saldaña, Johnny (2009). The coding manual for qualitative researchers. London: Sage.

Slobin, Dan I., \& Bocaz, Aura (1988). Learning to talk about movement through time and space: The development of narrative abilities in Spanish and English. Lenguas Modernas, 15, 5-24.

Sketch Engine [Language software]. https://www.sketchengine.eu/\#blue

Smith, Carlota S. (2003). Modes of discourse: The local structure of texts. Cambridge: Cambridge University Press.

Starren, Marianne (2001). The second time: The acquisition of temporality in French and Dutch as a second language. Utrecht: LOT.

Tracy, Sarah J. (2013). Qualitative research methods: Collecting evidence, crafting analysis, communicating impact. Malden: Wiley-Blackwell. Trévise, Anne (1987). Toward an analysis of the (inter)language activity of referring to time in narratives. In Carol Wollman Pfaff (Ed.), First and second language acquisition processes (pp. 225-251). Rowley: Newbury House.

United States Census Bureau (2010). QuickFacts. https://www.census.gov/quick facts/kentcityohio

Véronique, Daniel (1987). Reference to past events and actions in narratives in L2: Insights from North African workers' French. In Carol Wollman Pfaff (Ed.), First and second language acquisition processes (pp. 252-272). Rowley: Newbury House.

Virtanen, Tuija (1992). Temporal adverbials in text structuring: On temporal text strategy. In Ann-Charlotte Lindeberg, Nils E. Enkvist \& Kay Wikberg (Eds.), Nordic research on text and discourse: Nordtext Symposium 1990 (pp. 185-197). Åbo: Åbo Akademis Förlag.

Von Stutterheim, Christine, \& Klein, Wolfgang (1987). A concept-oriented approach to second language studies. In Carol W. Plaff (Ed.), First and second language acquisition processes (pp. 191-205). Rowley: Newbury House.

Whitworth, Anne; Classen, Mary; Leitão, Suze, \& Webster, Janet (2015). Beyond narrative: Is there an implicit structure to the way in which adults organize their discourse? Clinical Linguistics and Phonetics, 29(6), 455-481. 
Zwan, Rolf A. (1996). Processing narrative time shifts. Journal of Experimental Psychology: Learning, Memory, and Cognition, 22(5), 11961207.

Zwaan, Rolf A.; Madden, Carol J., \& Stanfield, Robert A. (2001). Time in narrative comprehension: A cognitive perspective. In Dick Schram \& Gerard J. Steen (Eds.), The psychology and sociology of literature (pp. 71-86). Amsterdam: John Benjamins. 


\section{Appendix}

Appendix A. Codebook Part I - Functions of Temporal Expressions Explanation and examples from the corpus

Main event. Expressions that specify when the main event of the narrative occurred.

(1) Todos cambiaron en el 27 de febrero.

'Everything changed on the 27th of February'.

Temporal organizers. Expressions that organize events, activities, or states with respect to one another or to the main event or place them on a timeline. These include (2a) anchorage markers or expressions that refer to an absolute time scale with either a time statement or a reference to one of the main divisions of the day (Bestgen \& Piérard, 2008) or point on a calendar; expressions that mark the ( $2 b$ ) beginning or (2c) end of an activity state or event; and (2d) two types of sequencers: sequentials, which indicate that "two or more situations are successive along the timeline" (Hickmann \& Hendriks, 2015: 104) and (2e) regionals, which mark "a situation in the same temporal region as another, including cases of inclusion and/or of partial or total overlap" (104).

(2) a. En la mañana, los chicos salieron.

'In the morning, the boys left'.

b. Diana y yo empezamos nuestro misión.

'Diana and I began our mission'.

c. Pronto el primer mes se acabó.

'Soon the first month ended'.

d. Después del ruido, solo hubo un gran silencio.

'After the noise, there was only a great silence'.

e. Caminé por la tienda con mi madre y yo esperaba mientras que ella se probaba unos vestidos.

'I walked through the store with my mother and I waited while she tried on some dresses'. 
Duration. Expressions that mark how long an event, activity, or state lasted.

(3) Lloré por una hora./ 'I cried for an hour'.

Repetition/frequency adverbials. Expressions that indicate an event, activity, or state was repeated or occurred more than once with either (4a) definite or (4b) indefinite frequency.

(4) a. Alguien le tiró dos veces en la cabeza. 'Someone shot him in the head two times'.

b. Cada semana andaba con un chica diferente en el corredor. 'Every week I would hang out in the hallways with a different girl'.

Manner adverbs with temporal features. Adverbials of manner that "are intermediate between time and manner interpretations" (Hasselgård, 2014: 32). They imply the passage of time by indicating the rate or velocity with which an action or event transpires.

(5) Exhalé lentamente./'I exhaled slowly'.

Discourse management. Expressions that contain words related to time semantically but whose primary pragmatic function is other than to "give the time of the event described, the time of the utterance itself, or specify any temporal relations between one or more events" (Morency, 2015: 1). These include (6a) topic management devices such as segmentation markers (Bestgen \& Costermans, 1997; Bestgen \& Piérard, 2008) and foreshadowing, (6b) emotional markers or intensifiers, (6c) transitional devices to bring the reader back to the present time, (6d) references to an indefinite future, and (6e) fillers that are redundant or unnecessary.

(6) a. Cada joven espera el día cuando - por fin - se obtiene la licencia de conducir. Es un momento en su vida que no olvidará. 
'Every teen waits for the day when - finally - she gets her driver's license. It is a moment in her life that she will not forget'.

b. No quise despertar nunca. 'I didn't want to ever get up'.

c. Yo soy más inteligente ahora, porqué aprendo sobre mis experiencias.

'I am more intelligent now because I learned from my experiences'.

d. Jamás haré de nuevo solo los cigarrillos y la cerveza son suficientes para mí.

'I will never do it again cigarettes and beer alone are sufficient for me'.

e. Aunque mi papá no es perfecto él amó las chicas en mi familia todos los días.

'Although my dad is not perfect he loved the girls in his family every day'.

Reported speech.

(7) Él gritó — ¡siéntate en la tierra! ¡Ahora!

'He shouted, "Sit down on the ground! Now!"

Homonyms and polysemous expressions. To track them, we coded, but did not include in our tabulations, words and phrases that often carry a temporal meaning, but which did not in the context used in a given point of a narrative.

(8) Pero, había trabajado entonces tenía dinero.

'But I had worked therefore [thus] I had money'. 
Appendix B. Codebook Part II - Syntax of Temporal Expressions

Explanation and examples from the corpus

Lexicalized adverbials and fixed adverbial phrases. Calendric adverbials (Starren, 2001) and other temporal connectors (Bustos Gisbert, 2014: 67) that are not separated into constituent parts but are used as is.

(9) La próxima mañana, me levante y fui a iglesia.

'The next morning, I got up and went to church'.

Nested or modified adverbs. Expressions where one adverb modifies another head adverb to make it more specific.

(10) Doce horas más tarde./ 'Twelve hours later'.

Constructed or nonlexicalized prepositional phrases. Distinct from fixed adverbial phrases, these prepositional phrases contain combinations of prepositions and noun phrases that are not typically collocated, but have been united by the writer for a specific context.

(11) Durante el accidente estaba tirada en el asiento del pasajero.

'During the accident I was thrown into the passenger seat'.

Noun phrases. Nouns and nominal expressions whose temporal reference is derived from the discursive context rather than lexical features of the noun itself. They include "event nouns" and those that "imply temporality in a restricted sense" (Fernández, 2009: 37), that is, by context.

(12) ¿Quién sabía que un episodio de mi juventud podría tan influyente? 'Who knew that an episode from my youth could [be] so influential?'

Temporal prepositions followed by an infinitive. In English, these would be followed by a gerund or a full clause rather than an infinitive. 
(13) Hablé con mi familia de acogida antes de salir. 'I talked with my host family before leaving'.

Subordinate clauses.

(14) Yo estaba durmiendo cuando oí un golpe en la puerta de mi cuarto. 'I was sleeping when I heard a knock on my bedroom door'.

Independent clauses.

(15) Terminamos la comida./ 'We finished the meal'.

Verbs semantically related to time. Verbs and semi-auxiliaries that mark "event phases" such as inception, protraction, continuation, or conclusion (Slobin \& Bocaz, 1988: 8).

(16) Empezamos montar las bicicletas./ 'We began to ride our bikes'.

Principle of Natural Order ( $P N O)$. Segments in which the events are related in the order they occurred with no intervening temporal connector and segments in which sequencing is implied by conventional implicature (Grice, 1975) with the coordinating conjunction $y$ or and.

(17) Me di cuenta de necesitaba dinero. Me excusé de la mesa para usar el cajero automático. Inserté la tarjeta y entré los números personales. 'I realized I needed money. I excused myself from the table to use the automatic teller. I inserted the card and I entered my personal code'.

Expressions with inseparable, multiple expressions of time. Clauses and phrasal temporal expressions that contain more than one element that refers to time.

(18) El 19 del augusto, 2007 era el día que mi vida cambió para siempre. 'The 19th of August, 2007 was the day my life changed forever'. 